\title{
ELEMENTS OF PSYCHOLOGY REQUIRED IN THE PASTORAL MISSIONARY ACTIVITY OF THE PRIEST IN THE PRESENT SOCIETY
}

\author{
Elena-Ancuța Santi \\ Teacher Training Department, Valahia University Targoviste, Romania. \\ E-mail: santi.anca@yahoo.ro
}

\begin{abstract}
The priest's mission has always been special, unique, intended to intercede between God and His believers, by relating to the threefold mission of Christ the Savior, i.e. the teaching, sanctifying and guiding mission. The present society and all rapid changes occurring in connection with it generate mutations at psychological and spiritual level, alienate people, promote false values, misbalance and anxiousness, continuous pursuit of the meaning of life, individualism and lack of empathy. The priest's service requires skills and calling which reflect both in one's personal life and the life of the believer, by acquiring the well-being, harmony with oneself, with the people around, with God. The priest should be a model, a landmark, an unshakable pillar, a scholar, an educated man, with authentic moral principles and values, whose life in family and in society should reflect godly principles. Moreover, the priest should be a good psychologist, observe changes, know people's personalities, counsel, guide, know how to get close to people and help them in line with their personal needs. On the other hand, he should have good self-knowledge, abilities to manage his personal emotions and feelings, powerful intrinsic motivation; he should also be a person of character and moral conduct. This paper aims to highlight the necessity of the psychological skills in the priest's life and pastoral missionary activity and their positive valences.
\end{abstract}

Keywords: pastoral missionary activity; pastoral psychology; vocation;

\section{INTRODUCTION}

The present society is continuously evolving at a rapid pace to which man has to face; however, man does not always have the internal and/or external resources required to do so. Although he has numerous means to communicate and relate to others, his drama springs from this very fact: the information technique and science may not replace the genuine communication and bond between two persons and, in such a dialogue, neither of the two partners truly listens to the other. Everybody talks and nobody listens, it is a ,dialogue of the deaf" (Jurca, 2010, p. 187), in which man gets to the point when he fails listening to himself, he depersonalizes himself and becomes an individual in a crowd instead of a person, with a unique and unrepeatable personality, an individual who is valuable in the light of his face, the face of his Creator.

The negative effects of the scientific progress are found in the desacralization and devaluation tendency which is becoming increasingly obvious. In this environment, man often loses himself, gets confused and tries to rediscover the best path with the help of his 
father confessor. The contemporary man's problems are profound and they concern pursuit of the meaning of life, filling the existential void.

Emotionally unstable, unaccomplished, spiritually sick, insecure, frustrated, more and more people seek the support of the Church or the psychologist in order to find their balance and the balance of their entire life and to harmonize different levels of their existence: spiritual, emotional, family-related, social, professional levels.

Man's relationship with God provides life with vitality, inner and outer balance, harmony in relation to himself and the others, and the priest's role is fundamental in this context. The pastoral missionary work of the Church is always carried out here and now, yet in the dimension of an eternal hic et nunc, updating the redeeming mission and work of Jesus the Savior. It addresses man and his soul; this is the reason why the priest should also be a good psychologist.

Priesthood means par excellence serving God as well as people, and it implies dedication, kindness and understand one's kind, tradition and innovation, maintaining the relevant truths and also adapting to the changes of the present time.

\section{CALLING AND SKILLS REQUIRED IN SERVING AS A PRIEST}

The calling represents the meeting point between God and man, between the individual's divine level and their inner propensities (Jurca, 2010, p. 44). The very etymology of the word calling, of the Latin verb voco, vocare, which means to call, to convoke, to invoke, makes reference to the meaning of calling which expects an answer. Therefore, the calling represents vocation, predisposition, propensity to something, manifested by interest in or love for that particular something (Braniște, 2014, p. 48). P. Popescu-Neveanu (1978, p. 776) defines calling as ,,a coherent synthesis of instrumental forces and moral and social values, an optimal interaction between the skills for something and the attitudes to the same something within the framework of a high axiological consciousness and based on a vigorous tendency for overachievement". The same author claims that the actions concerning professional orientation, for instance, seek to support the young toward making a decision in favor of the vocational professional role so that they may engage in acquiring the profession which best fits their real interests and skills.

Calling is a natural, inborn propensity or attraction to a field of activity which is based on an emotional foundation and psychophysical skills. It has a role in creating and maintaining a powerful motivation to accomplish the mission undertaken. The priest who has a true calling perceives his life and priesthood as a special, important mission, which brings meaning to his life, and mobilizes all his internal resources towards accomplishing such mission. The calling represents the main element which determines a priest or a psychologist to truly achieve their mission; in fact, a man of vocation identifies with their profession in all fields of activity (Braniște, 2014, p. 55).

Seen as a penchant or a special gift, special charism, inborn talent or natural calling (Jurca, 2009, p. 94), vocation is a requirement or a condition for those who choose to devote their life to helping their kind and fulfill God's will. The specific elements of the priest's pastoral missionary calling are: paying attention to others, not disregarding positive elements within others irrespective of the level of their moral decay at a given time, respecting their autonomy, expressing and manifesting one's respect and availability in relation to them (Tia, 2004-2005, p. 30). 
Priest professor E. Braniște (2014, p. 56) shows that the vocation or the calling to priesthood may be objective (extraordinary or ordinary, depending on how it is fulfilled) or subjective, psychological (as an inner inborn predisposition to priesthood).

E. Jurca (2009, pp. 93-119) identifies the following skills which should form part of the priest's profile, without limiting to:

- professional training, professional experience and professionalism;

- knowledge and permanent training;

- ethical conduct;

- most profound self-knowledge;

- self-acceptance;

- personal authenticity;

- psycho-emotional and spiritual maturity;

- communication skills and communicability;

- empathy;

- listening skills;

- balanced self-esteem;

- therapeutic/ moral-soteriological responsibility;

- sense of humor;

- intelligence and wisdom;

- sense of observation;

- patience, calm, consistency, balance, emotional stability;

- discretion, being worthy of trust;

- credibility, correctness, impartiality;

- flexibility, understanding, indulgence, power of compassion;

- optimism.

In addition, love for people, love for one's kind is very important; without it, all the other would be insufficient.

\section{ELEMENTS OF PSYCHOLOGY REQUIRED IN THE PRIEST'S WORK}

Among the first special qualities that a priest should possess in order to accomplish his mission are the abilities to understand the mysteries of the human soul, i.e. a priest should be a good psychologist, understand the spiritual needs of the believers, provide each believer with the best advice possible for that specific point in time and help them recover. These qualities are mostly the qualities of a father confessor whose mission is so difficult that he has to impose the penitent a church canon that is neither too difficult to follow, avoiding therefore dismay and loss of the believer, nor too easy, so as not to create a false perception on the severity of their sins, being always helped by the divine spirit.

By the power of God's grace invested upon the service of the Mystery of Ordination, the father confessor weighs how much a believer may bear, he gives different advice to every believer, even though some believers' sins are similar, and prays for their lives to rediscover the right path. Father confessor applies the holy canons to help the penitent to heal. The purpose of such church canons is not to punish; on the contrary, they have a pedagogical thaumaturgical role (Santi, 2007, p. 148), are applied on a case-by-case basis, depending on the regrets, repentance and sorrows of the believer and their desire to recover and the determination not to mistake again. He has a mission and a huge responsibility of which he should be aware. When somebody comes before the priest, the latter has to listen, not to hurt. He has to provide good advice in order to heal the believer's grief. This unique psychological 
endeavor means that the father confessor should have that psychognosis typical of the persons who have grown in Christ (Răducă, 2014, p. 340).

It is essential that the father confessor should possess basic elements or notions of psychology, as only deep self-knowledge, profound understanding of oneself and one's self may help the priest to relate to the others in an accurate manner, to get to know the one with whom he interacts and therefore build an authentic relationship. Knowing various characteristics of various types of personality, for example, may be of great help to the priest serving as a father confessor. Similar to a teacher who builds the didactic approach in the light of their pupils' psychological and individual traits, their own learning speed and the unique characteristics of each pupil, the father confessor has to adapt his mission to the spiritual needs and necessities of each individual believer. It is therefore necessary for a priest to know the psychological mechanisms of the interpersonal relations and the laws of the human and spiritual evolution (Tia, 2004-2005, p. 33).

The priest's knowledge of psychology may help him discern between hysterical behaviors and powerful spiritual feelings, between hallucinations and visions, between emotional immaturity and the gift of tears, between neurotic guilt and moral culpability (Jurca, 2009, p. 205). It is obvious for all those reading the writings of the Holy Fathers or the great orthodox father confessors that they all had, beyond faith and Christian living, selfknowledge and wisdom, spiritual maturity, good understanding of psychology. They were really accomplished psychologists and researchers of human behavior, bringing into psychology the grace of Christian life (De Etna, 2003, p. 196). The father confessor has a difficult and important mission, the mission to provide believers with spiritual guidance. He plays a significant role in the harmonization of man's spiritual scope, by constant support toward going beyond one's limits and growing on a personal level. This is why the priest's psychotherapeutic activity is founded on the authentic Christian spiritual values which represent a barrier against the disintegration of one's personality and medicine in treating mental and physical diseases. The therapeutic power of the priest's mission is so great that healing spiritual wounds brings about improvement or cure of physical diseases or pains.

\section{PSYCHOLOGIST OR PRIEST?}

The priest's and the psychologist's mission is similar up to a point: whereas the psychologist seeks to bring man to equilibrium at psychological level, the priest aims to deify man, by using God's eternal word instead of a certain theory or vision of a psychological school. The psychologist searches the source of man's illness in their past traumatizing experiences, stored in their subconscious; the priest explores the soul and uses the Holy Sacraments to receive God's grace (Vlachos, 1998, p. 109). Psychology is an important, complex science, useful in certain moments of man's life; yet it knows that it is self-sufficient and recognizes the value of the faith in man's life, faith which has the power to help and support man toward becoming better, transfiguring himself and changing fundamentally.

In general, psychology consists of the psychological intervention conducted in a scientific manner and in spirit of humanism with a view to promoting health, optimization, self-knowledge and personal development so as to alter the psychological factors involved in the psychotic, psychosomatic and somatic disorders, as well as emergency situations and situations of risk (David, 2006, p. 83). Psychotherapy is the science which deals with treating the soul $($ psyche $=$ soul and therapeia $=$ treatment $)$.

The man-psychologist relationship may not be substituted by the manfather/confessor relationship or inversely, as each plays their role and operates on a different 
internal level. Nevertheless, they may be complementary. The first is a doctor-patient type of relation, while the second is a spiritual father-spiritual son type. God works in many different ways for man, this is why the psychologist may be an instrument of the divine help. However, the psychologist may not replace the priest, the divine grace, the Holy Sacraments and their effects on man. The psychologist is similar to a father confessor, but through whom God's Grace does not work; he is nothing but a person in whom one may confide. This is one of the most important distinctions between the priest and the psychologist. The relationship with one's father confessor is permanent and does not end after a certain number of sessions. It goes on through the father confessor's constant prayers and acquires God's grace on an ongoing basis (epektasis), continuing the process of deification toward resembling His Creator.

As a Holy Sacrament, the Confession is one of the most important spiritual works in man's life through its effects on the human soul, the renewal of the relationship with God and a profoundly spiritualizing metanoia. This Sacrament brings into man's being something unique and extremely powerful. It balances man spiritually and creates new perspectives of relating to God, to his kind and to one's own self.

The goal of the psychotherapy is to heal man, while the goal of the religion is to redeem him. Their mutual substitution or annulment is impossible. Yet, they may be complementary: the psychotherapy restores man's personality, whereas the confession renews man's mind and life. The former seeks to change a certain behavior and restructure one's personality, the latter focuses on spiritual healing and on opening a new perspective on life, following the Way of Truth and Life. The Sacrament goes beyond a mere emotional discharge. The pastoral relationship between a priest and a believer is much more than a mere psychological relation between two persons.

The difference between psychotherapy and confession resides in that the first is treatment and the second is sacrament, the first pursues psychological healing, the second targets spiritual healing. Psychotherapy pursues catharsis (unchaining, release, discharge of emotional pressure accumulated as a result of hidden trauma or certain psychological blockages), acquired by becoming aware and by therapeutic confession. Man who confesses is granted divine forgiveness and absolution, by the blessing of his father confessor, on the one hand, and God's grace, on the other hand. Whereas psychotherapy refers to present life on earth, Confession transcends space and time and prepares the believer for eternity (Jurca, 2009, p. 205).

Starting from the premise that the spiritual dimension of the human being may not be radically separated from the somatic and psychological dimension, one may speak of a new discipline related to theology and psychology, namely pastoral psychology, which may be defined as a set of knowledge and applications to the pastoral action of the contributions derived from the psychological sciences and the behavior-related sciences, with a view to supporting and helping the process of personal development and Christian growth (Jurca, 2009, p. 16). Pastoral psychology may be highly useful to the priest's mission, by combining theology and psychology knowledge; this is the reason why pastoral psychology is studied by clergymen both in the Western world and in America in order to prepare them at psychological level. Why should a priest have some basic training in psychology? It is not the consequence of the priest's intention to replace the expert, it is his need to get to know the limits of his skills and to be able to collaborate with or guide the person toward other relating services (Jurca, 2009, p. 125), when the scope of his competencies turns out to be limited. 
The religious and spiritual psychotherapy integrates the religious beliefs and practices in the psychological and social dimension of the human behavior and uses both traditional psychological therapeutic methods and religious elements, such as praying, going to holy church services, reading patristic books and the scriptures Contrary to other therapeutic approaches, the religious psychotherapy exploits the person's spiritual resources.

Taking into account that it is appropriate or even recommendable that the priest should have psychology knowledge to help him in getting to know the believers and in his special mission which he has to fulfill in relation to the Holy Table, one may say that the psychologist should also have some theological knowledge in order to provide appropriate advise and counsel to the persons who are in need of therapy. For instance, there are numerous professional organizations that have created religious or spiritual therapy programs, as they become increasingly aware of the importance of religion or spirituality in psychological therapies. An important aspect of the therapy which integrates religion and spirituality is helping patients to identify and overcome dysfunctional convictions which have generated the problems for which they are in therapy. Furthermore, therapy may help them connect or reconnect with the spiritual convictions which may prove to be liberating and helpful in solving their problems (Haug, 1998, pp. 181-194). Pargament (2007) claims that every time people come into the therapist's office they bring along their spiritual convictions, practices, experiences, values, relations and dilemmas. This complex of spiritual factors often becomes part, implicitly or explicitly, of the therapeutic process. Such therapy is the Religious Cognitive-Emotional Therapy - RCET, a new form of cognitive therapy which uses basic religious beliefs in psychotherapy. RCET is a combination of cognitive, humanist and existential theories, which relates to religious convictions, and has proven to be an efficient method of psychotherapy in treating the persons suffering from identity crises, depression, anxiety and other psychological disorders (Rajaei, 2010, p. 83).

\section{CONCLUSIONS}

Theology and psychology are two complementary and compatible fields which aim to provide assistance and support to those who are confident when addressing the priest or the psychologist. The spiritual help or internal balance represents the key to our happy existence and physical and mental health. The therapeutic role of the priest covers not only healing of spiritual wounds, but also man's deification, which is a much more important goal. Psychologists consider that man's psychological health is only about avoiding inner conflicts, creating and maintaining psychological balance.

In terms of faith, the inner balance may only be gained through direct cooperation with God's Grace that is gained through the Holy Mystery of Confession and the Holy Mystery of Eucharist by which man's relationship with God is restored and therefore man enjoys a renewal, a spiritual cleansing or a purification of the mind and the soul, which reinstates the human being's integrity affected by the sin. The loss of human's psychic harmony is, in most cases, an effect of disturbing the relationship with God (Baloyannis, 2015 , p. 256). As a profound mental experience, repentance constitutes the sign of becoming aware of one's mistakes, beginning of change and turning from evil. The psychological mechanism of repentance alters and restructures man, provides man with a direction and a positive path toward oneself, one's kind and God.

In addition to traditional roles, the priest nowadays is more and more requested to give advice, to counsel believers who are at different stages of crisis in their life (marital and family conflicts, major decisions to make, certain issues, mourning etc), which implies best 
psychological, theological and pedagogical skills training possible, developed networking and communication skills and abilities, updating knowledge in various fields, availability in terms of being devoted to working with people. More than ever, the priest should have an active mission in his parish and should get involved in the life of the community. Furthermore, the invigorating impetus of the holy teachings and the wisdom of the Holy Fathers are also highly needed at present.

\section{BIBLIOGRAPHY:}

[1] Baloyannis, S.I. (2015). Psihologie pastorală. Iași: Editura Doxologia.

[2] Braniște, E. (2014). Vocație și responsabilitate în slujirea preoțească. București: Editura Basilica.

[3] David, D. (2006). Psihologie clinică și psihoterapie. Fundamente. Iași: Editura Polirom.

[4] Haug, I.E. (1998). Including a spiritual dimension in family therapy. Ethical considerations, Contemporary Family Therapy. 20(2), 181-194. doi:10.1023/A:1025077425777.

[5] Hrisostom de Etna. (2003). .Elemente de Psihologie pastorală Ortodoxă. Galaţi: Editura Bunavestire.

[6] Jurca, E. (2009). Spovedanie şi Psihoterapie. Interferenţe şi diferenţe. Târgu Lăpuş: Editura Galaxia Gutenberg.

[7] Jurca, E. (2010). Criza sacerdotiului în stihiile lumii. Aspecte psihologice, re/orientări vocaţionale şi pastorale. Târgu Lăpuş: Editura Galaxia Gutenberg.

[8] Pargament, K.I. (2007). Spiritually Integrated Psychotherapy: Understanding and Addressing the Sacred. New York, NY, US: Guilford Press.

[9] Popescu-Neveanu, P. (1978). Dicționar de Psihologie. București: Editura Albatros.

[10] Rajaei, A.R. (2010). Religious Cognitive-Emotional Therapy: A New Form of Psychotherapy. Iranian Journal of Psychiatry, 5(3), 81-87.

[11] Retrieved from https://www.ncbi.nlm.nih.gov/pmc/articles/PMC3430504/.

[12] Răducă, V. (2014). Condiţionări şi riscuri psihologice în Sfânta Taină a Mărturisirii. In Misiune, Spiritualitate, Cultură. Târgovişte: Editura Valahia University Press, 336-354.

[13] Santi, C. (2007). Prevederi canonice privind Spovedania și Euharistia. In Adevărul și frumusețea credinței creștine. Târgoviște: Editura Arhiepiscopiei Târgoviștei, 146-157.

[14] Tia, T. (2004-2005). Noţiuni generale de Psihologie pastorală. Alba-Iulia.

[15] Vlachos, H. (1998). Psihoterapia ortodoxă. Ştiinţa Sfinţilor Părinţi. Timişoara: Editura Învierea. 